\title{
The roles of marginal lagoons in the maintenance of genetic diversity in the Brazilian migratory fishes Prochilodus argenteus and $P$. costatus
}

\author{
Bruno F. Melo ${ }^{1}$, Yoshimi Sato ${ }^{2}$, Fausto Foresti ${ }^{1}$ and Claudio Oliveira ${ }^{1}$
}

The rio São Francisco basin contains many endemic species, such as Prochilodus argenteus and P. costatus, which have great commercial importance. However, information about the main recruitment sites and genetic studies containing extensive sampling of these species are scarce. To investigate the roles of the marginal lagoons in the maintenance of genetic variability and in the population structure, we analyzed six microsatellite loci in nine sampling groups of $P$. argenteus and five sampling groups of $P$. costatus. Our results showed high levels of genetic variability and low values of genetic differentiation for $P$. argenteus $\left(F_{\mathrm{ST}}=0.008, P<0.05\right)$ and for $P$. costatus $\left(F_{\mathrm{ST}}=0.031, P<0.05\right)$. In addition, high values of gene flow combined with a small genetic distance suggest the presence of a single population for each species in the middle rio São Francisco basin. Moreover, putative migration routes involving marginal lagoons during the reproductive season could be detected, confirming the importance of these nurseries in the lifecycle of these species. Our results also indicate the necessity of adequate management of the fish resources and the conservation of the floodplains in the rio São Francisco basin.

A bacia do rio São Francisco contém muitas espécies endêmicas, tais como Prochilodus argenteus e P. costatus, os quais têm grande importância comercial. Entretanto, informações sobre as principais áreas de recrutamento e estudos genéticos contendo uma extensa amostragem dessas espécies no rio São Francisco são escassas. Para investigar o papel das lagoas marginais na manutenção da variabilidade genética e na estruturação populacional dessas espécies, nós analisamos seis loci microssatélites em nove grupos amostrais de $P$. argenteus e cinco grupos amostrais de $P$. costatus. Nossos resultados revelaram altos níveis de variabilidade genética para ambas as espécies e valores baixos de diferenciação genética para $P$. argenteus $\left(F_{\mathrm{ST}}=0.008, P\right.$ $<0.05)$ e $P$. costatus $\left(F_{\mathrm{ST}}=0.031, P<0.05\right)$. Adicionalmente, valores altos de fluxo gênico combinados com a distância genética baixa sugerem a presença de uma única população para cada espécie no médio rio São Francisco. Possíveis rotas migratórias envolvendo lagoas marginais durante o período reprodutivo puderam ser detectadas, confirmando a importância das lagoas marginais no ciclo de vida dessas espécies. Nossos resultados também indicaram a necessidade de um manejo adequado dos recursos pesqueiros e a conservação das várzeas na bacia do rio São Francisco.

Key words: Conservation genetics, Fish migration, Microsatellite, Nursery area, Rio São Francisco basin.

\section{Introduction}

The rio São Francisco basin constitutes an area that covers $619,543 \mathrm{~km}^{2}, c a .7 .5 \%$ of Brazil, with ecological domains ranging from Atlantic rainforest to Cerrado and Caatinga. In recent years, human impact, including the destruction of wetlands and marginal lagoons for agriculture and the construction of large dams, such as the Três Marias dam (TMD), for hydroelectric power generation, has affected the basin (Sato et al., 1987;
Menezes, 1996). The central portion of the rio São Francisco basin, including Três Marias region, has greater investment in the fishery (Camargo \& Petrere, 2001) and it is characterized by the presence of many floodplains and marginal lagoons. These marginal lagoons are important nursery habitats for migratory species recruitment because they provide an ideal habitat for the growth of juveniles with abundant food and relatively high temperatures (Moojen, 1940; Pompeu \& Godinho, 2003). Unfortunately, important aspects of the fish migrations in the

${ }^{1}$ Universidade Estadual Paulista - UNESP, Departamento de Morfologia, Instituto de Biociências, Rubião Jr. s/n, 18618-970 Botucatu, SP, Brazil.melo@ibb.unesp.br (BFM), fforesti@ibb.unesp.br(FF), claudio@ibb.unesp.br (CO)

${ }^{2}$ Estação de Hidrobiologia e Piscicultura de Três Marias, Companhia de Desenvolvimento dos Vales do São Francisco e do Parnaíba (CODEVASF-MG), 39205-000 Três Marias, MG, Brazil. sato.codevasf@gmail.com (YS) 
rio São Francisco, such as feeding and reproductive habitats, shoal composition and structure, homing and distances traveled between habitats, remain poorly studied (Sato \& Godinho, 2003).

Prochilodontids occur abundantly in the major drainages of South America and are considered one of the most important components of the commercial and subsistence fisheries in Neotropical freshwater environments (Lowe-McConnell, 1975; Goulding, 1981; Vari, 1983; Castro \& Vari, 2004). The family Prochilodontidae comprises three genera (Ichthyoelephas, Prochilodus, and Semaprochilodus) with highly restructured lips, teeth and jaws; these characteristics distinguish this family externally from all other characiforms (Castro \& Vari, 2004). Prochilodus argenteus, an endemic species from the rio São Francisco basin, nowadays introduced in other Neotropical drainages (Castro \& Vari, 2004), is the largest member of the Prochilodontidae family and is among the most important recreational and commercial fish species in the basin (Camargo \& Petrere, 2001; Godinho et al., 2003). Another endemic species, P. costatus, has an importance in the subsistence fishery, as one of the most captured species in that region (Camargo \& Petrere, 2001).

Genetic studies using variable markers such as microsatellites and mitochondrial DNA have been conducted to understand the population structure and dynamics of a considerable number of animal species (Zhang \& Hewitt, 2003). Microsatellites, or simple sequence repeats (SSRs), are codominant nuclear markers with Mendelian inheritance. Microsatellites are abundantly distributed along genomes and demonstrate high levels of allelic polymorphism (DeWoody \& Avise, 2000). The molecular structure and genetic variability of microsatellites are extensively exploited in evolutionary studies of a wide variety of fish species (see Chistiakov et al., 2006), including some from Neotropical freshwater (Hrbek et al., 2007; Abreu et al., 2009; Calcagnotto \& DeSalle, 2009; Matsumoto \& Hilsdorf, 2009; Pereira et al., 2009; Sanches et al., 2012).

Population genetic studies have been performed with both Prochilodus species from the rio São Francisco basin using Random Amplified Polymorphic DNA (RAPD) technique (Hatanaka \& Galetti, 2003) and microsatellites (Hatanaka et al., 2006; Carvalho-Costa et al. 2008; Sanches et al., 2012; Barroca et al., 2012). However, there is no knowledge about the main nursery areas of the populations of either species or the importance of the marginal lagoons in the maintenance of the genetic variability of these or other migratory species. Considering the threatened marginal regions of the middle rio São Francisco basin and the ecological and economic importance of these species, the goals of this study were to access the main recruitment sites of both species and provide a robust dataset regarding the population genetic structure of these species.

\section{Material and Methods}

\section{Sampling sites}

Migratory fishes reproduce in the mainstream or tributaries of the rio São Francisco basin, and their eggs and larvae are carried out downstream reaching marginal lagoons (Moojen, 1940) that stay unconnected of the mainstream in the dry season. Thus, samples collected in marginal lagoons were originated from spawning sites located upstream to the lagoons (e.g., samples collected in marginal lagoons from rio Paracatu was derived from eggs spawned only in upstream of the rio Paracatu). Thus, we consider samples from different lagoons of the same tributary as a single sampling group (Fig. 1, Table 1). We divided samples from the mainstream of rio São Francisco in the Três Marias region in three sampling groups to test previous ecological and genetic hypotheses that suggested a population differentiation among them (Godinho \& Kynard, 2006; Hatanaka et al., 2006). Additionally, individuals from Três Marias dam were subdivided in two different units (dry and rainy seasons) trying to check the presence of different migrant shoals inhabiting the same spawning site.

A total of 273 individuals, that were subdivided into nine sampling groups of Prochilodus argenteus, were collected between July 2008 and February 2010 along the middle rio São Francisco basin. Five sampling groups were from the marginal lagoons of their tributaries, rio Carinhanha (CAR, $\mathrm{n}=25$ ), rio Jequitaí (JEQ, $\mathrm{n}=33$ ), rio Paracatu (PAR, $\mathrm{n}=33$ ), rio Urucuia (URU, $\mathrm{n}=33$ ) and rio das Velhas (VEL, $\mathrm{n}=28$ ); one sampling group was from the marginal lagoons of the

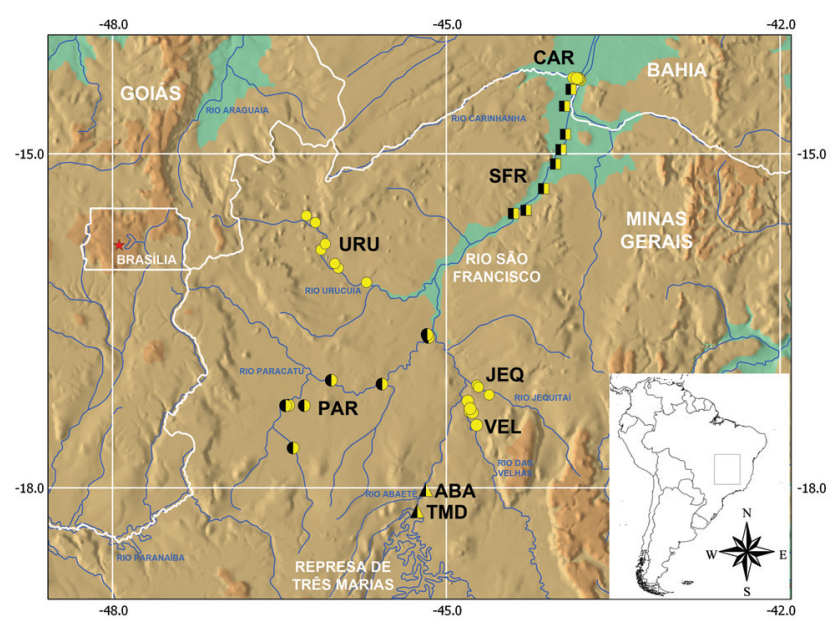

Fig. 1. Map showing the central portion of the rio São Francisco basin and the distribution of the samples of Prochilodus argenteus (yellow) and of P. costatus (black). The circles represent marginal lagoons from tributaries, squares represent marginal lagoons from the rio São Francisco, and triangles represent places in the mainstream rio São Francisco in the Três Marias region. $\mathrm{ABA}=$ rio Abaeté; $\mathrm{CAR}=$ rio Carinhanha lagoons; JEQ = rio Jequitaí lagoons; $\mathrm{PAR}=$ rio Paracatu lagoons; SFR = rio São Francisco lagoons; $\mathrm{URU}=$ rio Urucuia lagoons; VEL = rio das Velhas lagoons; $\mathrm{TMD}=$ Três Marias Dam. 
Table 1. Samples of Prochilodus argenteus and P. costatus from the rio São Francisco basin collected between July/2008 and July/2010. Samples from TMDr and ABAr were collected during the rainy season (November to February), and samples from TMDd were collected during the dry season (March to October). $\mathrm{ABAr}=$ rio Abaeté at rainy season; $\mathrm{CAR}=$ rio Carinhanha lagoons; JEQ = rio Jequitaí lagoons; PAR = rio Paracatu lagoons; SFR = rio São Francisco lagoons; URU = rio Urucuia lagoons; $\mathrm{VEL}=$ rio das Velhas lagoons; $\mathrm{TMDd}=$ Três Marias Dam at dry season; $\mathrm{TMDr}=$ Três Marias Dam at rainy season.

\begin{tabular}{|c|c|c|c|c|c|}
\hline Locality & Sampling & Geographical coordinates & Abbreviation & $P . \operatorname{argenteus}(\mathrm{n})$ & P. costatus $(\mathrm{n})$ \\
\hline \multirow[t]{3}{*}{ Três Marias Region } & Downstream to & $18^{\circ} 12^{\prime} 32^{\prime \prime} \mathrm{S} 45^{\circ} 15^{\prime} 41^{\prime \prime} \mathrm{W}$ & TMDd & 33 (dry) & 33 (dry) \\
\hline & Três Marias Dam & & TMDr & 22 (rainy) & 26 (rainy) \\
\hline & Downstream to rio Abaeté & $18^{\circ} 01^{\prime} 01^{\prime \prime} \mathrm{S} 45^{\circ} 10^{\prime} 56^{\prime \prime} \mathrm{W}$ & $\mathrm{ABAr}$ & 33 (rainy) & 31 (rainy) \\
\hline \multirow[t]{8}{*}{ Rio São Francisco Lagoons } & Lagoa Lapinha & $14^{\circ} 57^{\prime} 45^{\prime \prime} \mathrm{S} 43^{\circ} 58^{\prime} 10^{\prime \prime} \mathrm{W}$ & SFR & 33 & 33 \\
\hline & Lagoa Grande & $15^{\circ} 30^{\prime} 27^{\prime \prime} \mathrm{S} 44^{\circ} 17^{\prime} 04^{\prime \prime} \mathrm{W}$ & & & \\
\hline & Lagoa Beirada & $14^{\circ} 34^{\prime} 19^{\prime \prime} \mathrm{S} 43^{\circ} 56^{\prime} 15^{\prime \prime} \mathrm{W}$ & & & \\
\hline & Lagoa Lavagem & $14^{\circ} 49^{\prime} 30^{\prime \prime} \mathrm{S} 43^{\circ} 55^{\prime} 46^{\prime \prime} \mathrm{W}$ & & & \\
\hline & Lagoa Maris & $14^{\circ} 25^{\prime} 17^{\prime \prime} \mathrm{S} 43^{\circ} 52^{\prime} 42^{\prime \prime} \mathrm{W}$ & & & \\
\hline & Lagoa Ipueira & $15^{\circ} 32^{\prime} 11^{\prime \prime} \mathrm{S} 44^{\circ} 23^{\prime} 44^{\prime \prime} \mathrm{W}$ & & & \\
\hline & Lagoa Cajueiro & $15^{\circ} 05^{\prime} 29^{\prime \prime} \mathrm{S} 44^{\circ} 01^{\prime} 07^{\prime \prime} \mathrm{W}$ & & & \\
\hline & Lagoa Banguê & $15^{\circ} 18^{\prime} 46^{\prime \prime} \mathrm{S} 44^{\circ} 07^{\prime} 30^{\prime \prime} \mathrm{W}$ & & & \\
\hline \multirow[t]{5}{*}{ Rio Das Velhas Lagoons } & Lagoa Periperi & $17^{\circ} 26^{\prime} 14^{\prime \prime} \mathrm{S} 44^{\circ} 43^{\prime} 40^{\prime \prime} \mathrm{W}$ & VEL & 28 & - \\
\hline & Lagoa Tiririca & $17^{\circ} 13^{\prime} 33^{\prime \prime} \mathrm{S} 44^{\circ} 48^{\prime} 27^{\prime \prime} \mathrm{W}$ & & & \\
\hline & Lagoa Capivara & $17^{\circ} 18^{\prime} 50^{\prime \prime} \mathrm{S} 44^{\circ} 47^{\prime} 16^{\prime \prime} \mathrm{W}$ & & & \\
\hline & Lagoa Maria Joana & $17^{\circ} 19^{\prime} 30^{\prime \prime} \mathrm{S} 44^{\circ} 45^{\prime} 57^{\prime \prime} \mathrm{W}$ & & & \\
\hline & Lagoa do Saco & $17^{\circ} 17^{\prime} 21^{\prime \prime} \mathrm{S} 44^{\circ} 47^{\prime} 08^{\prime \prime} \mathrm{W}$ & & & \\
\hline \multirow[t]{3}{*}{ Rio Jequitaí Lagoons } & Lagoa Cascalho & $17^{\circ} 09^{\prime} 55^{\prime \prime} \mathrm{S} 44^{\circ} 36^{\prime} 54^{\prime \prime} \mathrm{W}$ & JEQ & 33 & - \\
\hline & Lagoa Lagoão & 17 $04^{\prime} 39^{\prime \prime} \mathrm{S} 44^{\circ} 43^{\prime} 30^{\prime \prime} \mathrm{W}$ & & & \\
\hline & Lagoa Tapera & $17^{\circ} 05^{\prime} 46^{\prime \prime} \mathrm{S} 44^{\circ} 42^{\prime} 40^{\prime \prime} \mathrm{W}$ & & & \\
\hline \multirow[t]{7}{*}{ Rio Paracatu Lagoons } & Lagoa Piranhas & $16^{\circ} 38^{\prime} 54^{\prime \prime} \mathrm{S} 45^{\circ} 09^{\prime} 39^{\prime \prime} \mathrm{W}$ & PAR & 33 & 33 \\
\hline & Lagoa Faz. Sertaneja & $17^{\circ} 04^{\prime} 07^{\prime \prime} \mathrm{S} 45^{\circ} 34^{\prime} 42^{\prime \prime} \mathrm{W}$ & & & \\
\hline & Lagoa Ferradura & $17^{\circ} 02^{\prime} 03^{\prime \prime} \mathrm{S} 46^{\circ} 02^{\prime} 03^{\prime \prime} \mathrm{W}$ & & & \\
\hline & Lagoa Redonda & $17^{\circ} 15^{\prime} 43^{\prime \prime} \mathrm{S} 46^{\circ} 16^{\prime} 38^{\prime \prime} \mathrm{W}$ & & & \\
\hline & Lagoa Neves & $17^{\circ} 38^{\prime} 33^{\prime \prime} \mathrm{S} 46^{\circ} 22^{\prime} 38^{\prime \prime} \mathrm{W}$ & & & \\
\hline & Lagoa Água Limpa & $16^{\circ} 37^{\prime} 24^{\prime \prime} \mathrm{S} 45^{\circ} 10^{\prime} 20^{\prime \prime} \mathrm{W}$ & & & \\
\hline & Lagoa Názara & $17^{\circ} 15^{\prime} 43^{\prime \prime} \mathrm{S} 46^{\circ} 26^{\prime} 38^{\prime \prime} \mathrm{W}$ & & & \\
\hline \multirow[t]{7}{*}{ Rio Urucuia Lagoons } & Lagoa Cinquenta & $16^{\circ} 09^{\prime} 18^{\prime \prime} \mathrm{S} 45^{\circ} 43^{\prime} 01^{\prime \prime} \mathrm{W}$ & URU & 33 & - \\
\hline & Lagoa Sucupira & $15^{\circ} 37^{\prime} 01^{\prime \prime} \mathrm{S} 46^{\circ} 10^{\prime} 33^{\prime \prime} \mathrm{W}$ & & & \\
\hline & Lagoa Encantada & $16^{\circ} 01^{\prime} 34^{\prime \prime} \mathrm{S} 45^{\circ} 58^{\prime} 15^{\prime \prime} \mathrm{W}$ & & & \\
\hline & Lagoa Silvério & $15^{\circ} 59^{\prime} 06^{\prime \prime} \mathrm{S} 46^{\circ} 00^{\prime} 07^{\prime \prime} \mathrm{W}$ & & & \\
\hline & Lagoa Taboada & $15^{\circ} 33^{\prime} 22^{\prime \prime} \mathrm{S} 46^{\circ} 15^{\prime} 30^{\prime \prime} \mathrm{W}$ & & & \\
\hline & Lagoa Capão Grosso & $15^{\circ} 51^{\prime} 47^{\prime \prime} \mathrm{S} 46^{\circ} 07^{\prime} 36^{\prime \prime} \mathrm{W}$ & & & \\
\hline & Lagoa Piranhas & $15^{\circ} 48^{\prime} 32^{\prime \prime} \mathrm{S} 46^{\circ} 05^{\prime} 14^{\prime \prime} \mathrm{W}$ & & & \\
\hline \multirow[t]{5}{*}{ Rio Carinhanha Lagoons } & Lagoa Água Branca & $14^{\circ} 19^{\prime} 08^{\prime \prime} \mathrm{S} 43^{\circ} 51^{\prime} 18^{\prime \prime} \mathrm{W}$ & CAR & 25 & - \\
\hline & Lagoa Peixe Gordo & $14^{\circ} 20^{\prime} 09^{\prime \prime} \mathrm{S} 43^{\circ} 47^{\prime} 48^{\prime \prime} \mathrm{W}$ & & & \\
\hline & Lagoa Pau Branco & $14^{\circ} 19^{\prime} 28^{\prime \prime} \mathrm{S} 43^{\circ} 48^{\prime} 28^{\prime \prime} \mathrm{W}$ & & & \\
\hline & Lagoa Morrinhos & $14^{\circ} 19^{\prime} 39^{\prime \prime} \mathrm{S} 43^{\circ} 48^{\prime} 55^{\prime \prime} \mathrm{W}$ & & & \\
\hline & Lagoa Rio Velho & $14^{\circ} 19^{\prime} 22^{\prime \prime} \mathrm{S} 43^{\circ} 49^{\prime} 35^{\prime \prime} \mathrm{W}$ & & & \\
\hline Total & & & & 273 & 156 \\
\hline
\end{tabular}

rio São Francisco (SFR, $\mathrm{n}=33$ ); two sampling groups were collected downstream of the Três Marias dam, one during rainy season $(\mathrm{TMDr}, \mathrm{n}=22$ ) and one during dry season (TMDd, $\mathrm{n}=33$ ); and one sampling group was collected downstream rio Abaeté during the rainy season (ABAr, $\mathrm{n}=$ 33) (Fig. 1, Table 1). In reference to P. costatus, a total of 156 individuals subdivided into five sampling groups were collected along the middle rio São Francisco basin. One sampling group was collected in the marginal lagoons of rio Paracatu (PAR, $\mathrm{n}=33$ ); one sampling group was from marginal lagoons of the rio São Francisco basin (SFR, $n=$ 33 ); two sampling groups were collected downstream of the Três Marias dam, one group was obtained during the rainy season (TMDr, $\mathrm{n}=26)$ and one was obtained during the dry season (TMDd, $\mathrm{n}=33$ ); and one sampling group was from downstream rio Abaeté during the rainy season (ABAr, $n=$ 31) (Fig. 1, Table 1). All of the fish used for this study were collected in accordance with Brazilian laws under a permanent scientific collection license. Fin clips or muscles were fixed and preserved in $95 \%$ ethanol and deposited in the Laboratório de Biologia e Genética de Peixes, Universidade Estadual Paulista "Júlio de Mesquita Filho", câmpus de Botucatu, São Paulo, Brazil.

Molecular analyses. Genomic DNA was extracted using a saline solution with proteinase K described by Aljanabi \& Martinez (1997). Amplifications were carried out using six microsatellite loci developed by Barbosa et al. (2008) for Prochilodus argenteus: Par66, Par69, Par71, Par76, Par83 and Par85; the same loci were used for P. costatus, exception the locus Par80 was used instead of Par76 (monomorphic for this species). The reactions were performed in a total volume of $12.5 \mu \mathrm{l}$ with $7.3 \mu \mathrm{l}$ of ultrapure $\mathrm{H}_{2} \mathrm{O}, 1.25 \mu \mathrm{l}$ of Taq DNA buffer (10X), $0.45 \mu \mathrm{l}$ of $\mathrm{MgCl}_{2}(50 \mathrm{mM}), 0.4 \mu \mathrm{l}$ of dNTP $(2 \mathrm{mM}), 0.5 \mu \mathrm{l}$ 
of each primer $(10 \mu \mathrm{M}), 0.1 \mu \mathrm{l}$ of Platinum Taq DNA Polymerase enzyme (Invitrogen; www.invitrogen.com) $(5 \mathrm{U} / \mu \mathrm{l})$ and $2.0 \mu \mathrm{l}$ of genomic DNA (10-50 ng). Polymerase chain reactions (PCR) consisted of an initial denaturation step $\left(5 \mathrm{~min}\right.$ at $\left.95^{\circ} \mathrm{C}\right)$ followed by 35 cycles of chain denaturation $\left(30 \mathrm{~s}\right.$ at $\left.95^{\circ} \mathrm{C}\right)$, primer hybridization $\left(30 \mathrm{~s}\right.$ at $\left.52-54^{\circ} \mathrm{C}\right)$ and nucleotide extension $\left(30 \mathrm{~s}\right.$ at $\left.72^{\circ} \mathrm{C}\right)$. After these cycles, a final extension was performed at $72^{\circ} \mathrm{C}$ for 10 minutes. Microsatellite amplified fragments were subjected to electrophoresis on $6 \%$ polyacrylamide gels for approximately 12 hours at $150 \mathrm{v}$. The gels were then stained with silver nitrate. The allele lengths were identified by reference to a 10 bp ladder (Invitrogen) using Kodak Digital Science 1D software.

\section{Population genetic analyses}

Allele numbers, private allele counts and gene flow (Nm $\left.=0.25\left(1-F_{\mathrm{ST}}\right) / F_{\mathrm{ST}}\right)$ were obtained with Popgene $1.32($ Yeh $\&$ Boyle, 1997). To construct and export the matrices, we used GenAlex 6.1 (Peakall \& Smouse, 2006). The expected and observed heterozygosity (He, Ho), inbreeding coefficient $F_{\text {IS }}$ (Wright, 1951) were obtained with Arlequin 3.1 (Excoffier et al., 2005). The software Microchecker 2.2.1 (van Oosterhout et al., 2004) using the equation 2 of Brookfield (1996) was used to infer the most probable cause of HWE departures produced for null alleles, stuttering and large-allele dropout. The exact test of the HardyWeinberg Equilibrium $(\mathrm{HWE})(P$-value $<0.05)$ were calculated with 1 million generations of Marchov chain of Monte Carlo (MCMC) with 100,000 'burn-ins' using Arlequin 3.1 (Excoffier et al., 2005). Significance levels for the HWE, F- and R-statistics tests were adjusted using Bonferroni corrections (Rice, 1989). The linkage disequilibrium was calculated for all loci using Genepop 4.0.1 online (Raymond \& Rousset, 1995).

The $F_{\mathrm{ST}}$ (Wright, 1951) assuming the infinite allele model (IAM, Kimura \& Crow, 1964), the $R_{\mathrm{ST}}$ (Slatkin, 1995) assuming the stepwise mutation model (SMM, Kimura \& Otha, 1978) and the analysis of molecular variance (AMOVA) (Excoffier et al., 1992) calculated for all loci and for all populations with 16,000 permutations (Guo \& Thomson, 1992) were performed using the Arlequin 3.1 program (Excoffier et al., 2005). Initially, the samplings of Prochilodus argenteus were considered to be a single group for the AMOVA. Then, the samplings were subdivided into two groups: group 1 (adult fishes collected at mainstream of Três Marias region - ABAr, TMDd, and TMDr) and group 2 (juveniles collected inside unconnected marginal lagoons - SFR, VEL, JEQ, PAR, URU, and CAR). Similarly, the populations of $P$. costatus were first considered to be a single group and then subdivided into two groups: group 1 (adult fishes collected at mainstream of Três Marias region - ABAr, TMDd, and TMDr) and group 2 (juveniles collected inside unconnected marginal lagoons - LSF and PAR). This criterion was adopted to answer where are the main recruitment areas of the fishes found in the mainstream of Três Marias region (the most fishery activity of the São Francisco basin). In addition, rates of chord genetic distance (Cavalli-Sforza \& Edwards, 1967) corrected for sample size were calculated with Geneclass2 (Piry et al., 2004), and these values were used to construct an unrooted neighbor-joining tree (Saitou \& Nei, 1987) using the software Paup 4.0b10 (Swofford, 2003).

\section{Results}

\section{Prochilodus argenteus}

Genotypes of 273 specimens of nine sampling groups were analyzed. All microsatellite loci were highly polymorphic. A total of 99 alleles were detected for all loci in all populations. The number of alleles per locus ranged from three (Par76) to 24 (Par85), with an overall average of 9.6 alleles (Table 2 ). Nineteen private alleles were found in low frequency $(\leq 0.05)$ with the allele 239 (Par85 - URU), presenting a frequency of 0.052 . Ho and He ranged from 0.379 (Par69) to 0.937 (Par71) and 0.473 (Par69) to 0.951 (Par85), respectively (Table 2). From the 54 pairwise $F_{\text {IS }}$ estimates, 41 showed positive values (heterozygote deficiency), and only 13 showed negative values (an excess of heterozygotes). Positive $F_{\text {Is }}$ values indicating heterozygote deficiency was predominant in all loci with a positive overall average $\left(F_{\text {IS }}=0.123, P<0.008\right)$ (Table 2$)$. Only six out of $54 \mathrm{HWE}$ tests performed for $P$. argenteus (6 microsatellite loci in 9 sampling groups) were significant. In all departure occurrences, the significant values of disequilibrium were associated with the presence of null alleles (Table 2). Null alleles were detected in 14 estimates and stutters were verified only in Par85 in the population TMDr. No evidence of linkage disequilibrium was detected in any loci $(P>0.05)$.

Low indices of $F_{\mathrm{ST}}$ obtained by means of pairwise values among local populations of Prochilodus argenteus for all loci were significantly detected $\left(F_{\mathrm{ST}}=0.008, P<\right.$ 0.05 ), with pairwise $F_{\mathrm{ST}}$ for all loci ranging from -0.054 (ABA - JEQ) to 0.007 (ABAr - TMDd) (Table 3, above diagonal), clearly indicating an absence of population structure. Additionally, the overall $R_{\mathrm{ST}}$ also showed significant lower values $\left(R_{\mathrm{ST}}=0.059, P<0.05\right)$, ranging from -0.460 (ABAr - PAR) to 0.184 (TMDr - PAR) (Table 3, bellow diagonal). When we considered all specimens to be a single group (see Material and Methods), the AMOVA values (Table 4) revealed that only $0.82 \%$ of the total genetic variance was due to differences among populations $\left(F_{\mathrm{ST}}=0.008, P<0.05 ; R_{\mathrm{ST}}=0.069, P<0.05\right)$ and $99.18 \%$ of the genetic variation within populations. When we considered the putative existence of two groups (see Material and Methods), the hierarchical AMOVA also revealed that $99.13 \%$ of the total variance was found within populations (values are shown in the Table 4).

The gene flow parameter $\mathrm{Nm}$ was calculated from the mean $F_{\mathrm{ST}}$ value. The mean value obtained was $\mathrm{Nm}=9.318$, 
Table 2. Summary of the six microsatellite loci for each analyzed sampling of Prochilodus argenteus. $N$, number of individuals; A, number of alleles; P, number of private alleles; Ho, observed heterozygosity; He, expected heterozygosity; $F_{\text {IS }}$, inbreeding coefficient; HWE, probability test for deviation from expected Hardy-Weinberg proportions, *, $P$-value $=0.05$ (adjustment Bonferroni correction $P \leq 0,008 ; K=6$ ); $r$, null alleles frequency per loci. ABAr = rio Abaeté at rainy season; CAR $=$ rio Carinhanha lagoons; JEQ = rio Jequitaí lagoons; PAR = rio Paracatu lagoons; LSF = rio São Francisco lagoons; URU = rio Urucuia lagoons; $\mathrm{VEL}=$ rio das Velhas lagoons; $\mathrm{TMDd}=$ Três Marias Dam at dry season; $\mathrm{TMDr}=$ Três Marias Dam at rainy season.

\begin{tabular}{|c|c|c|c|c|c|c|c|c|c|c|c|c|c|}
\hline Sampling & $\begin{array}{c}\text { Loci } \\
\text { Par66 } \\
\end{array}$ & Par69 & Par71 & Par76 & Par83 & Par85 & Sampling & $\begin{array}{c}\text { Loci } \\
\text { Par66 } \\
\end{array}$ & Par69 & Par71 & Par76 & Par83 & Par85 \\
\hline ABAr & & & & & & & JEQ & & & & & & \\
\hline$N$ & 30 & 32 & 22 & 30 & 31 & 21 & $N$ & 32 & 33 & 26 & 14 & 18 & 28 \\
\hline $\mathrm{A} / \mathrm{P}$ & 09/1 & $5 / 0$ & $10 / 0$ & $5 / 0$ & $12 / 0$ & $15 / 1$ & $\mathrm{~A} / \mathrm{P}$ & $7 / 0$ & $7 / 0$ & $11 / 0$ & $4 / 0$ & $10 / 1$ & $19 / 1$ \\
\hline Но & 0.733 & 0.656 & 0.682 & 0.666 & 0.677 & 0.428 & Ho & 0.875 & 0.636 & 0.807 & 0.643 & 0.611 & 0.750 \\
\hline $\mathrm{He}$ & 0.787 & 0.641 & 0.860 & 0.732 & 0.844 & 0.927 & $\mathrm{He}$ & 0.789 & 0.624 & 0.865 & 0.717 & 0.839 & 0.946 \\
\hline$F_{\text {IS }}$ & 0.069 & -0.023 & 0.211 & 0.091 & 0.200 & 0.543 & $F_{\text {IS }}$ & -0.110 & -0.018 & 0.068 & 0.106 & 0.278 & 0.210 \\
\hline HWE & 0.473 & 0.026 & 0.018 & 0.565 & 0.132 & $0.000 *$ & HWE & 0.771 & 0.881 & 0.009 & 0.262 & 0.088 & 0.012 \\
\hline$r$ & - & - & 0.515 & - & 0.195 & 0.641 & $r$ & - & - & - & - & 0.652 & 0.308 \\
\hline TMDd & & & & & & & PAR & & & & & & \\
\hline$N$ & 30 & 31 & 19 & 32 & 26 & 28 & $N$ & 33 & 32 & 25 & 29 & 24 & 27 \\
\hline $\mathrm{A} / \mathrm{P}$ & $8 / 0$ & $07 / 1$ & $12 / 2$ & $4 / 0$ & $16 / 1$ & $18 / 0$ & $\mathrm{~A} / \mathrm{P}$ & $08 / 1$ & $7 / 0$ & $15 / 1$ & $4 / 0$ & $9 / 0$ & $21 / 3$ \\
\hline Ho & 0.833 & 0.451 & 0.789 & 0.687 & 0.769 & 0.750 & Но & 0.848 & 0.656 & 0.840 & 0.483 & 0.708 & 0.740 \\
\hline $\mathrm{He}$ & 0.799 & 0.568 & 0.901 & 0.688 & 0.904 & 0.947 & $\mathrm{He}$ & 0.823 & 0.693 & 0.916 & 0.678 & 0.834 & 0.951 \\
\hline$F_{\text {IS }}$ & -0.043 & 0.208 & 0.127 & 0.001 & 0.151 & 0.211 & $F_{\text {IS }}$ & -0.030 & 0.054 & 0.085 & 0.291 & 0.153 & 0.224 \\
\hline HWE & 0.488 & 0.079 & 0.079 & 0.533 & 0.056 & $0.002 *$ & HWE & 0.051 & 0.258 & 0.125 & 0.094 & 0.048 & $0.000 *$ \\
\hline$r$ & - & - & - & - & - & 0.309 & $r$ & - & - & - & 0.319 & - & 0.349 \\
\hline TMDr & & & & & & & URU & & & & & & \\
\hline$N$ & 20 & 19 & 19 & 22 & 22 & 19 & $N$ & 33 & 29 & 16 & 17 & 31 & 29 \\
\hline $\mathrm{A} / \mathrm{P}$ & $7 / 0$ & $4 / 0$ & $10 / 0$ & $3 / 0$ & $13 / 1$ & $16 / 0$ & $\mathrm{~A} / \mathrm{P}$ & $7 / 0$ & $5 / 0$ & $8 / 0$ & $4 / 0$ & $15 / 1$ & $16 / 1$ \\
\hline Ho & 0.800 & 0.526 & 0.737 & 0.727 & 0.818 & 0.737 & Ho & 0.818 & 0.379 & 0.937 & 0.706 & 0.838 & 0.482 \\
\hline $\mathrm{He}$ & 0.774 & 0.621 & 0.850 & 0.669 & 0.860 & 0.939 & $\mathrm{He}$ & 0.823 & 0.565 & 0.863 & 0.693 & 0.890 & 0.923 \\
\hline$F_{\text {IS }}$ & -0.034 & 0.156 & 0.137 & -0.089 & 0.050 & 0.219 & $F_{\text {IS }}$ & 0.006 & 0.333 & -0.089 & -0.018 & 0.059 & 0.481 \\
\hline HWE & 0.640 & 0.033 & 0.426 & 0.326 & 0.211 & 0.048 & HWE & 0.341 & $0.001 *$ & 0.636 & 0.545 & 0.019 & $0.000 *$ \\
\hline$r$ & - & - & - & - & - & 0.292 & $r$ & - & 0.334 & - & - & - & 0.385 \\
\hline LSF & & & & & & & CAR & & & & & & \\
\hline$N$ & 27 & 29 & 26 & 27 & 28 & 30 & $N$ & 23 & 21 & 21 & 24 & 21 & 21 \\
\hline $\mathrm{A} / \mathrm{P}$ & $7 / 0$ & $6 / 0$ & $12 / 0$ & $4 / 0$ & $13 / 0$ & $20 / 0$ & $\mathrm{~A} / \mathrm{P}$ & $9 / 0$ & $5 / 0$ & $12 / 2$ & $4 / 0$ & $13 / 0$ & $16 / 0$ \\
\hline Ho & 0.778 & 0.379 & 0.807 & 0.518 & 0.785 & 0.933 & Ho & 0.869 & 0.523 & 0.714 & 0.583 & 0.762 & 0.809 \\
\hline $\mathrm{He}$ & 0.746 & 0.646 & 0.890 & 0.740 & 0.865 & 0.951 & $\mathrm{He}$ & 0.793 & 0.473 & 0.877 & 0.703 & 0.888 & 0.933 \\
\hline$F_{\text {IS }}$ & -0.042 & 0.417 & 0.094 & 0.303 & 0.093 & 0.019 & $F_{\text {IS }}$ & -0.098 & -0.108 & 0.189 & 0.173 & 0.145 & 0.136 \\
\hline HWE & 0.834 & 0.009 & 0.099 & 0.038 & 0.831 & 0.672 & HWE & 0.482 & 0.807 & 0.031 & 0.159 & 0.019 & 0.053 \\
\hline$r$ & - & 0.356 & - & 0.392 & - & - & $r$ & - & - & - & - & - & - \\
\hline \multicolumn{14}{|l|}{ VEL } \\
\hline$N$ & 26 & 17 & 25 & 25 & 14 & 20 & & & & & & & \\
\hline $\mathrm{A} / \mathrm{P}$ & $7 / 0$ & $06 / 1$ & $8 / 0$ & $4 / 0$ & $9 / 0$ & $17 / 0$ & & & & & & & \\
\hline Ho & 0.807 & 0.588 & 0.760 & 0.640 & 0.643 & 0.650 & & & & & & & \\
\hline $\mathrm{He}$ & 0.767 & 0.693 & 0.851 & 0.703 & 0.830 & 0.939 & & & & & & & \\
\hline$F_{\text {IS }}$ & -0.054 & 0.155 & 0.109 & 0.091 & 0.232 & 0.313 & & & & & & & \\
\hline HWE & 0.469 & 0.230 & 0.697 & 0.664 & 0.092 & $0.000 *$ & & & & & & & \\
\hline$r$ & - & - & - & - & - & 0.495 & & & & & & & \\
\hline
\end{tabular}

Table 3. Pairwise $F_{\mathrm{ST}}$ (above diagonal) and pairwise $R_{\mathrm{ST}}$ (bellow diagonal) values for Prochilodus argenteus. $* P<0.05$, after Bonferroni correction. $\mathrm{ABAr}=$ rio Abaeté at rainy season; $\mathrm{CAR}=$ rio Carinhanha lagoons; JEQ = rio Jequitaí lagoons; $\mathrm{PAR}=$ rio Paracatu lagoons; SFR = rio São Francisco lagoons; URU = rio Urucuia lagoons; VEL = rio das Velhas lagoons; $\mathrm{TMDd}=$ Três Marias Dam at dry season; TMDr = Três Marias Dam at rainy season.

\begin{tabular}{cccccccccc}
\hline & ABAr & TMDd & TMDr & SFR & VEL & JEQ & PAR & URU & CAR \\
\hline ABAr & - & 0.007 & -0.000 & -0.005 & -0.038 & -0.054 & 0.005 & -0.015 & 0.001 \\
TMDd & 0.079 & - & -0.007 & -0.004 & -0.021 & -0.042 & -0.003 & -0.018 & -0.003 \\
TMDr & -0.006 & -0.007 & - & 0.002 & -0.037 & -0.052 & -0.005 & -0.025 & -0.001 \\
SFR & -0.012 & 0.024 & -0.040 & - & -0.037 & -0.038 & -0.002 & -0.021 & -0.001 \\
VEL & -0.107 & 0.059 & -0.201 & -0.031 & - & -0.040 & -0.013 & -0.062 & -0.018 \\
JEQ & -0.101 & 0.114 & -0.117 & 0.006 & 0.031 & - & -0.019 & -0.027 & -0.051 \\
PAR & -0.460 & $0.184^{*}$ & 0.013 & $0.117^{*}$ & 0.015 & $0.138^{*}$ & - & -0.023 & 0.002 \\
URU & -0.032 & 0.020 & -0.005 & -0.005 & -0.127 & -0.032 & -0.000 & - & -0.028 \\
CAR & -0.015 & 0.064 & -0.026 & 0.007 & -0.090 & -0.013 & 0.016 & -0.017 & - \\
\hline
\end{tabular}


Table 4. Analysis of Molecular Variance (AMOVA) among sampling groups of Prochilodus argenteus. Structure tested: All samplings as a single group and divided in two groups: group 1 (Mainstream ABAr, TMDd and TMDr) and group 2 (Marginal lagoons of CAR, JEQ, PAR, SFR, URU and VEL).

\begin{tabular}{clcccc}
\hline $\begin{array}{c}\text { Hierarchical } \\
\text { model }\end{array}$ & Source of variation & $\begin{array}{c}\text { Variance } \\
\text { components }\end{array}$ & $\begin{array}{c}\text { Percentage } \\
\text { of variation }\end{array}$ & $F$-statistics & $P$-value \\
\hline \multirow{2}{*}{ One group } & Among populations & 0.019 & 0.824 & $F_{\mathrm{ST}}=0.008$ & $P<0.05$ \\
& Within populations & 2.395 & 99.175 & - & - \\
\hline \multirow{2}{*}{ Two groups } & Among groups & 0.002 & 0.105 & $F_{\mathrm{CT}}=0.001$ & $P>0.05$ \\
& Among populations within groups & 0.018 & 0.766 & $F_{\mathrm{SC}}=0.007$ & $P<0.05$ \\
& Within populations & 2.395 & 99.127 & - & - \\
\hline
\end{tabular}

indicating an intense gene exchange occurring among all sampling groups. The gene flow values within each group (group 1: ABAr, TMDd, TMDr; and group 2: CAR, JEQ, PAR, SFR, URU, VEL) were $\mathrm{Nm}=12.065$ and $\mathrm{Nm}=10.331$, respectively. The pairwise values of chord distance were estimated and ranged from $24.0 \%$ (JEQ - PAR) to $35.3 \%$ (ABAr - URU) (Table 5), and the dendrogram of genetic distance showed a low genetic differentiation among sampling groups analyzed (Fig. 2).

\section{Prochilodus costatus}

Five sampling groups with a total of 156 specimens were analyzed. All loci used in the analysis were highly polymorphic with a total of 112 alleles for all loci in all sampling groups. The number of alleles per locus ranged from four (Par69) to 29 (Par85), with an overall average of 12.9 alleles (Table 6). Nineteen private alleles were found at low frequency (d" 0.04). The observed heterozygosity ranged from 0.231 (Par69) to 0.958 (Par71), and the expected heterozygosity ranged from 0.580 (Par69) to 0.960 (Par85). The $F_{\text {IS }}$ indexes showed 24 comparisons with positive values

Table 5. Chord genetic distance among sampling of Prochilodus argenteus. Values in \%. $\mathrm{ABAr}=$ rio Abaeté at rainy season; $\mathrm{CAR}=$ rio Carinhanha lagoons; $\mathrm{JEQ}=$ rio Jequitaí lagoons; $\mathrm{PAR}=$ rio Paracatu lagoons; $\mathrm{SFR}=$ rio São Francisco lagoons; URU = rio Urucuia lagoons; $\mathrm{VEL}=$ rio das Velhas lagoons; TMDd = Três Marias Dam at dry season; $\mathrm{TMDr}=$ Três Marias Dam at rainy season.

\begin{tabular}{|c|c|c|c|c|c|c|c|c|}
\hline & $\mathrm{ABAr}$ & MDd & MDr & SFR & VEL & JEQ & PAR & URU CAR \\
\hline ABAr & - & & & & & & & \\
\hline TMDd & 32.7 & - & & & & & & \\
\hline TMDr & 28.4 & 27.3 & - & & & & & \\
\hline SFR & 29.4 & 23.8 & 27.2 & - & & & & \\
\hline VEL & 31.0 & 31.9 & 29.0 & 25.2 & - & & & \\
\hline JEQ & 26.7 & 30.0 & 27.9 & 24.7 & 27.8 & - & & \\
\hline PAR & 31.2 & 29.1 & 29.2 & 28.7 & 28.4 & 24.0 & - & \\
\hline URU & 35.3 & 29.0 & 32.0 & 31.1 & 32.4 & 31.5 & 30.7 & - \\
\hline CAR & 29.7 & 28.4 & 28.2 & 27.6 & 26.9 & 29.3 & 29.8 & 31.5 \\
\hline
\end{tabular}

(heterozygote deficiency) and six comparisons with negative values (excess of heterozygotes). The deficiency of heterozygotes was predominant in all loci with a positive overall average $\left(F_{\text {IS }}=0.113, P<0.008\right)$ (Table 6$)$. Only seven out of $30 \mathrm{HWE}$ tests performed for $P$. costatus (6 microsatellite loci in 5 sampling groups) were significant, and of these, six estimates were associated with the presence of null alleles (Table 6). Presence of stutters was verified in the Par71 loci on PAR. No linkage disequilibrium was detected $(P>0.05)$, and the allelic variation was treated independently.

Our results indicate a significant absence of the population structure based on $F_{\mathrm{ST}}=0.031, P<0.05$ and $R_{\mathrm{ST}}$ $=0.044, P<0.05$. In addition, pairwise $F_{\mathrm{ST}}$ values do not indicated structuring in all estimatives, ranging from -0.005 to 0.049 . Median $R_{\mathrm{ST}}$ values were detected between SFR and TMDd $\left(R_{\mathrm{ST}}=0.113, P<0.05\right)($ Table 7$)$. Considering no predefined hierarchical models, the AMOVA showed that $96.82 \%$ of the genetic variance was found within

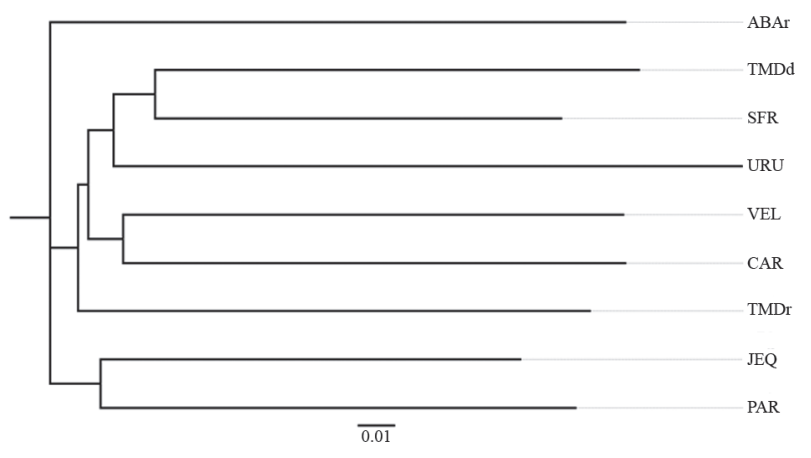

Fig. 2. Dendrogram representing the chord genetic distance among sampling groups of Prochilodus argenteus. $\mathrm{ABAr}=$ rio Abaeté at rainy season; $\mathrm{CAR}=$ rio Carinhanha lagoons; $\mathrm{JEQ}=$ rio Jequitaí lagoons; PAR = rio Paracatu lagoons; SFR = rio São Francisco lagoons; URU = rio Urucuia lagoons; $\mathrm{VEL}=$ rio das Velhas lagoons; TMDd = Três Marias Dam at dry season; TMDr = Três Marias Dam at rainy season. 
Table 6. Summary of the six microsatellite loci for each analyzed sampling of Prochilodus costatus. $N$, number of individuals; A, number of alleles; P, number of private alleles; Ho, observed heterozygosity; He, expected heterozygosity; $F_{\text {IS }}$, inbreeding coefficient; HWE, probability test for deviation from expected Hardy-Weinberg proportions, ${ }^{*}, P$-value $=0.05$ (adjustment Bonferroni correction $P \leq 0.008 ; K=6) ; r$, null alleles frequency per loci. $\mathrm{ABAr}=$ rio Abaeté at rainy season; PAR $=$ rio Paracatu lagoons; LSF = rio São Francisco lagoons; TMDd = Três Marias Dam at dry season; TMDr= Três Marias Dam at rainy season.

\begin{tabular}{|c|c|c|c|c|c|c|}
\hline \multirow{2}{*}{ Sampling } & \multicolumn{6}{|c|}{ Loci } \\
\hline & Par66 & Par69 & Par71 & Par80 & Par83 & Par85 \\
\hline \multicolumn{7}{|l|}{$\mathrm{ABAr}$} \\
\hline$N$ & 30 & 28 & 29 & 30 & 26 & 31 \\
\hline $\mathrm{A} / \mathrm{P}$ & $6 / 0$ & $7 / 0$ & $16 / 1$ & $13 / 0$ & $15 / 0$ & $26 / 5$ \\
\hline Ho & 0.833 & 0.535 & 0.827 & 0.600 & 0.692 & 0.935 \\
\hline $\mathrm{He}$ & 0.741 & 0.731 & 0.915 & 0.710 & 0.904 & 0.960 \\
\hline$F_{\text {IS }}$ & -0.126 & 0.270 & 0.097 & 0.158 & 0.238 & 0.026 \\
\hline HWE & 0.320 & $0.001 *$ & 0.044 & 0.077 & 0.016 & 0.717 \\
\hline$r$ & - & 0.278 & - & - & 0.335 & - \\
\hline \multicolumn{7}{|l|}{ TMDd } \\
\hline$N$ & 33 & 26 & 31 & 33 & 26 & 32 \\
\hline $\mathrm{A} / \mathrm{P}$ & $7 / 1$ & $5 / 1$ & $16 / 1$ & $16 / 2$ & $12 / 0$ & $22 / 0$ \\
\hline Но & 0.788 & 0.231 & 0.742 & 0.909 & 0.731 & 0.906 \\
\hline $\mathrm{He}$ & 0.803 & 0.615 & 0.915 & 0.912 & 0.879 & 0.946 \\
\hline$F_{\mathrm{IS}}$ & 0.020 & 0.629 & 0.192 & 0.003 & 0.171 & 0.043 \\
\hline HWE & 0.388 & $0.000 *$ & $0.000 *$ & 0.367 & 0.087 & 0.019 \\
\hline$r$ & - & 0.511 & 0.187 & - & - & - \\
\hline \multicolumn{7}{|l|}{ TMDr } \\
\hline$N$ & 25 & 26 & 24 & 26 & 25 & 26 \\
\hline $\mathrm{A} / \mathrm{P}$ & $7 / 0$ & $4 / 0$ & $16 / 1$ & $10 / 1$ & $16 / 0$ & $17 / 0$ \\
\hline Ho & 0.720 & 0.577 & 0.958 & 0.500 & 0.880 & 0.846 \\
\hline $\mathrm{He}$ & 0.734 & 0.580 & 0.930 & 0.843 & 0.908 & 0.939 \\
\hline$F_{\mathrm{IS}}$ & 0.020 & 0.006 & -0.031 & 0.411 & 0.032 & 0.101 \\
\hline HWE & 0.332 & 0.607 & $0.000 *$ & $0.000 *$ & 0.292 & 0.129 \\
\hline$r$ & - & - & - & 0.178 & - & - \\
\hline \multicolumn{7}{|l|}{ LSF } \\
\hline$N$ & 28 & 18 & 25 & 27 & 22 & 25 \\
\hline $\mathrm{A} / \mathrm{P}$ & $7 / 0$ & $6 / 0$ & $16 / 0$ & $17 / 1$ & $13 / 0$ & $18 / 1$ \\
\hline Но & 0.750 & 0.666 & 0.680 & 0.889 & 0.909 & 0.800 \\
\hline $\mathrm{He}$ & 0.782 & 0.647 & 0.903 & 0.865 & 0.889 & 0.936 \\
\hline$F_{\mathrm{IS}}$ & 0.042 & -0.030 & 0.251 & -0.028 & -0.023 & 0.148 \\
\hline HWE & 0.050 & 0.612 & $0.002 *$ & 0.210 & 0.489 & 0.109 \\
\hline$r$ & - & - & 0.431 & - & - & - \\
\hline \multicolumn{7}{|l|}{ PAR } \\
\hline$N$ & 29 & 31 & 29 & 31 & 19 & 28 \\
\hline $\mathrm{A} / \mathrm{P}$ & $7 / 0$ & $6 / 0$ & $14 / 0$ & $16 / 1$ & $17 / 1$ & $21 / 2$ \\
\hline Ho & 0.724 & 0.677 & 0.620 & 0.774 & 0.947 & 0.786 \\
\hline $\mathrm{He}$ & 0.812 & 0.730 & 0.914 & 0.874 & 0.927 & 0.942 \\
\hline$F_{\mathrm{IS}}$ & 0.110 & 0.073 & 0.325 & 0.116 & -0.022 & 0.168 \\
\hline HWE & 0.215 & 0.656 & $0.000 *$ & 0.074 & 0.988 & 0.057 \\
\hline$r$ & - & - & 0.322 & - & - & 0.290 \\
\hline
\end{tabular}

populations $\left(F_{\mathrm{ST}}=0.031, P<0.05 ; R_{\mathrm{ST}}=0.044, P<0.05\right)$. When we considered the putative existence of two groups (see Material and Methods) the estimates remain almost unchanged with the most of the variation within the populations $\left(96.66 \%\right.$ ) with $F_{\mathrm{ST}}=0.033, P<0.05$ (values are shown in Table 8).

The mean value of gene flow obtained for Prochilodus costatus was $\mathrm{Nm}=5.911$, and the values within each group (group 1: ABAr, TMDd, TMDr; and group 2: PAR, SFR) were $\mathrm{Nm}=6.698$ and $\mathrm{Nm}=13.010$, respectively, showing a higher number of migrants per generation. The chord distance ranged from 32.6\% (TMDr - PAR) to 39.6\% (SFR ABAr) (Table 9). The SFR sample group has more discrepant indexes, which is shown in the dendrogram (Fig. 3).

\section{Discussion}

\section{Genetic diversity and lack of genetic structuring}

In the present study, we did not find any genetic evidence of the existence of population structure in the species Prochilodus argenteus or P. costatus from the middle rio São Francisco basin. The population differentiation indexes $F_{\mathrm{ST}}$ and $R_{\mathrm{ST}}$, the chord genetic distance associated to a high gene flow and previous studies (Carvalho-Costa et al., 2008; Sanches et al., 2012) corroborate the panmictic unit model for both species. The migration behavior, which is common in prochilodontids (Castro \& Vari, 2004) likely plays an important role in the continuous gene flow in these species, keeping them as a single unit in the studied area. 
Table 7. Pairwise $F_{\mathrm{ST}}$ (above diagonal) and pairwise $R_{\mathrm{ST}}$ (bellow diagonal) values for Prochilodus costatus. ${ }^{*} P<0.05$, after Bonferroni correction. $\mathrm{ABAr}=$ rio Abaeté at rainy season; $\mathrm{PAR}=$ rio Paracatu lagoons; $\mathrm{SFR}=$ rio São Francisco lagoons; TMDd $=$ Três Marias Dam at dry season; TMDr = Três Marias Dam at rainy season.

\begin{tabular}{llllll}
\hline & ABAr & TMDd & TMDr & SFR & PAR \\
\hline ABAr & - & $0.017^{*}$ & $0.049^{*}$ & $0.040^{*}$ & $0.039^{*}$ \\
TMDd & 0.052 & - & $0.031^{*}$ & $0.020^{*}$ & $0.017^{*}$ \\
TMDr & 0.001 & -0.010 & - & $0.018^{*}$ & -0.005 \\
SFR & 0.054 & $0.113^{*}$ & 0.064 & - & 0.005 \\
PAR & 0.012 & $0.062^{*}$ & -0.010 & 0.011 & - \\
\hline
\end{tabular}

Variability levels in microsatellites with a mean number of 9.6 alleles per locus in Prochilodus argenteus and 12.9 alleles per locus in P. costatus were similar to those reported in freshwater fish with an average of 9.1 alleles per locus (DeWoody \& Avise, 2000) and were similar to or higher than previous studies with both Prochilodus species (Hatanaka et al., 2006; Carvalho-Costa et al., 2008; Sanches et al., 2012). High genetic diversity was previously identified in P. lineatus (Sivasundar et al., 2001), which can be explained by the capacity of Prochilodus species to perform great migrations and by their large occurrence along the rivers. In the rio São Francisco basin, shoals of $P$. argenteus are capable of migrating up to $1,100 \mathrm{~km}$ upstream to spawn (Pinheiro, 1981), while in the rio MogiGuaçu (upper rio Paraná basin), P. lineatus migrates a maximum round trip distance of 1,300 km (Godoy, 1975; Toledo et al., 1986).

Significant deviations from the HWE were found in only six microsatellite loci of Prochilodus argenteus. These deviations are common in microsatellite regions (Alam \& Islam, 2005; Carreras-Carbonell et al., 2006; Chevolot et al., 2006). Hatanaka et al. (2006) found populations with significant deviations from HWE in two of the four analyzed loci. The occurrence of null alleles and stuttering seems to be the most probable cause of these deviations because all of the deviations were associated with the occurrence of null alleles. Additionally, $F_{\text {IS }}$ values in $P$. costatus were positive in $80 \%$ of the estimates, also observed previously in the same species (Carvalho-Costa et al., 2008).
However, we found low levels of population genetic differentiation among local populations of Prochilodus argenteus, as indicated by all population analyses, including $F_{\mathrm{ST}}$ values that were lower $(0.008, P<0.05)$ than $R_{\mathrm{ST}}$ values $(0.059, P<0.05)$. The $R_{\mathrm{ST}}$ values under the SMM are expected to be greater than the $F_{\mathrm{ST}}$ values under the IAM (Slatkin, 1995), although the inverse has been observed in some fish species (e.g., Pereira et al., 2009). Low indexes of $F_{\mathrm{ST}}$ have been observed in other studies with characiforms, such as in Colossoma macropomum (Santos et al., 2007), Piaractus mesopotamicus (Calcagnotto \& DeSalle, 2009; Iervolino et al., 2010), Prochilodus argenteus (Hatanaka et al., 2006; Sanches et al., 2012), Prochilodus costatus (Carvalho-Costa et al., 2008), Prochilodus lineatus (Revaldaves et al., 1997) and Salminus brasiliensis (Lopes et al., 2007).

The overall $F_{\mathrm{ST}}$ found in $P$. argenteus $(0.008, P<0.05)$ is similar to that found for the same species $\left(F_{\mathrm{ST}}=0.008, P=\right.$ 0.0002, Hatanaka et al., 2006). However, these authors suggested a model of structured population based on the occurrence of private alleles and high levels of heterozygosity found in one local population. Our results do not show any genetic structure (pairwise $F_{\mathrm{ST}}$ ) among sampling groups from the Três Marias region, any differences in the heterozygosity, or the presence of exclusive alleles. Thus, we suggest the existence of only one panmictic unit of $P$. argenteus in the central portion of the rio São Francisco basin based on $F_{\mathrm{ST}}, R_{\mathrm{ST}}$ and chord genetic distance.

Similarly, our results do not show the existence of a genetic structure in Prochilodus costatus. The $F_{\mathrm{ST}}$ and $R_{\mathrm{ST}}$ indexes found here were significantly low $\left(F_{\mathrm{ST}}=0.031, P<0.05 ; R_{\mathrm{ST}}=\right.$ $0.044, P<0.05$ ) with a high levels of gene flow (mean of $\mathrm{Nm}=$ 5.911 ), confirming the null hypothesis of the absence of a population structure. This hypothesis, evidenced by fixation rates is also supported by the homogeneous genetic distance (Table 9). These results corroborate those of Carvalho-Costa et al. (2008), who found low levels of pairwise structuring $\left(F_{\mathrm{ST}}=-0.009\right.$ and 0.006$)$ in populations collected downstream of Três Marias dam, the rio Abaeté and the confluence among the two rivers at the reproductive season.

\section{Migratory routes}

Migratory fishes from the rio São Francisco basin spawn only in the reproductive season, which extends from

Table 8. Analysis of Molecular Variance (AMOVA) among sampling groups of Prochilodus costatus. Structure tested: All samplings as a single group and divided in two groups: group 1 (Mainstream ABAr, TMDd and TMDr) and group 2 (Marginal lagoons of PAR and SFR).

\begin{tabular}{llcccc}
\hline Structure tested & Source of variation & $\begin{array}{c}\text { Variance } \\
\text { components }\end{array}$ & $\begin{array}{c}\text { Percentage } \\
\text { of variation }\end{array}$ & $F$-statistics & $P$-value \\
\hline \multirow{2}{*}{ Single group } & Among populations & 0.083 & 3.187 & $F_{\mathrm{ST}}=0.031$ & $P<0.05$ \\
& Within populations & 2.523 & 96.812 & - & - \\
\hline \multirow{2}{*}{ Two groups } & Among groups & 0.010 & 0.383 & $F_{\mathrm{CT}}=0.003$ & $P>0.05$ \\
& Among populations within groups & 0.077 & 2.953 & $F_{\mathrm{SC}}=0.029$ & $P<0.05$ \\
& Within populations & 2.523 & 96.663 & - & - \\
\hline
\end{tabular}


Table 9. Chord genetic distance among sampling of Prochilodus costatus. Values in \%. ABAr $=$ rio Abaeté at rainy season; PAR = rio Paracatu lagoons; SFR = rio São Francisco lagoons; TMDd $=$ Três Marias Dam at dry season; TMDr $=$ Três Marias Dam at rainy season.

\begin{tabular}{lccccc}
\hline & ABAr & TMDd & TMDr & SFR & PAR \\
\hline ABAr & - & & & & \\
TMDd & 33.6 & - & & & \\
TMDr & 36.2 & 35.2 & - & & \\
SFR & 39.6 & 37.5 & 38.7 & - & \\
PAR & 34.8 & 33.5 & 32.6 & 35.9 & - \\
\hline
\end{tabular}

November to February and coincides with the occurrence of rain and flooding, higher temperatures, and long photoperiods (Sato et al., 1996; Sato \& Godinho, 2003). After total spawning in the mainstream river or in tributaries, eggs and larvae of the migratory fishes are carried downstream by water flow reaching marginal lagoons, which provide essential habitats for juveniles with an abundant food and relatively high temperatures (Moojen, 1940). During the dry season, the marginal lagoons become isolated from the main channel. At the next rainy season, flooding provides water connections, and juveniles are ready to return to the main river (Sato \& Godinho, 2003). Migrations to spawn can explain the existence of a higher number of migrants per generation observed in our analysis (Prochilodus argenteus, $\mathrm{Nm}=9.318 ;$ P. costatus, $\mathrm{Nm}=$ 5.911). Wright (1931) suggests that values greater than one migrant per generation prevent the substantial local differentiation by genetic drift. In fact, the existence of a

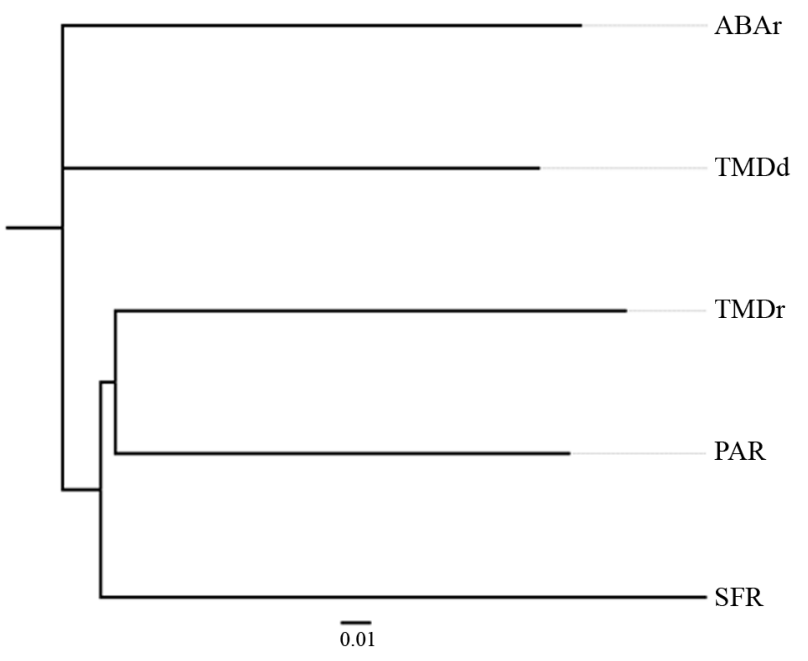

Fig. 3. Dendrogram representing the chord genetic distance among sampling groups of Prochilodus costatus. $\mathrm{ABAr}=$ rio Abaeté at rainy season; $\mathrm{PAR}=$ rio Paracatu lagoons; $\mathrm{SFR}=$ rio São Francisco lagoons; TMDd $=$ Três Marias Dam at dry season; $\mathrm{TMDr}=$ Três Marias Dam at rainy season. single panmictic population for each species associated with the highly migratory behavior support the hypothesis of extensive gene flow among shoals.

The convergence between rio São Francisco and rio Abaeté is considered the most important spawning site of Prochilodus argenteus (Godinho \& Kynard, 2006), mainly because of the limnological conditions offered by the junction of the two rivers, such as water flow above $600 \mathrm{~m}^{3} /$ $\mathrm{s}$, water temperature over $24^{\circ} \mathrm{C}$ and concentrations of dissolved oxygen above $5 \mathrm{mg} / \mathrm{l}$ (Sato et al., 2005). As suggested by Hatanaka \& Galetti (2003), one fraction completes its migration toward the dam during the reproductive period, and the majority possibly migrates to locations with environmental conditions more favorable for reproduction. Sato et al. (2005) found individuals with greater body size and weight and with better reproductive conditions downstream of the rio Abaeté compared with individuals that were collected upstream under the influence of the Três Marias dam. Observations made over the past 25 years as well as reports from local fishermen also relate the downstream confluence of the rio Abaeté and rio São Francisco as a preferential spawning site of other migratory fishes from this basin, such as Brycon orthotaenia, Conorhynchos conirostris, Pseudoplatystoma corruscans, and Salminus franciscanus (Sato et al., 2005).

Considering two hypothetic scenarios for Prochilodus argenteus, first as a single population and second as divided into two groups, the degree of variation detected by AMOVA among populations was minimal $\left(F_{\mathrm{ST}}=0.008, P<0.05\right)$, and variation among the groups was not detected $\left(F_{\mathrm{CT}}=0.001\right.$, $P>0.05)$. These results show that the samples belonging to the Três Marias region (group 1) are not isolated from those recruited in the marginal lagoons (group 2). Based on these data, we can suggest that the populations of $P$. argenteus, which are recruited in the tributary lagoons, migrate preferentially to the mainstream of the rio São Francisco in the feeding season and then migrate to the Três Marias region or randomly return to the headwaters of tributaries during the reproductive season. In addition, the $F_{\mathrm{ST}}, R_{\mathrm{ST}}$, AMOVA and chord distance could not detect a population genetically distinct from the other populations that possessed similarity with individuals collected downstream rio Abaeté during the rainy season. Thus, this important area (downstream of the rio Abaeté) does not receive individuals of $P$. argenteus from one exclusive region but instead receives individuals from many regions along the middle rio São Francisco basin, that it must lead to a population homogenization.

\section{Contributions of the marginal lagoons for migratory fishes}

The floodplain area from the central rio São Francisco basin was estimated to be about 2,000 $\mathrm{km}^{2}$ (Welcomme, 1990). The importance of the marginal lagoons in the recruitment of fishes was previously estimated by Sato et al. (1987), identifying 37 juveniles including migratory species such as Prochilodus argenteus $(<70 \mathrm{~g})$ and $P$. costatus $(<80 \mathrm{~g})$. 
Our results indicate a high gene flow with low genetic differentiation among samples from both marginal lagoons and mainstream rio São Francisco, suggesting a direct connectivity among these shoals.

The continuous and rapid advancement of agriculture and the subsequent sediment deposition in some of the important tributaries from the central basin (Sato \& Godinho, 2003) are factors that directly affect the conservation of the lagoons. Notwithstanding, Pompeu \& Godinho (2006) observed a gradual reduction in fish richness and an abundance of lagoons that did not receive annual flooding because of the water flow control by the Três Marias hydroelectric dam. Local extinction with a reduction of almost $70 \%$ of the native fish fauna was also observed in a lagoon from the rio São Francisco basin (Pompeu \& Alves, 2003). Considering these fish nurseries in the rio São Francisco basin (Sato \& Godinho, 2003) and upper rio Paraná (Agostinho et al., 2000), the Brazilian conservation policy should include these marginal lagoons in the floodplains as a priority for the maintenance of the genetic variability in migratory fishes.

\section{Acknowledgments}

This paper benefited from comments and suggestions from Fábio F. Roxo, Fernando F. Mendonça and Luiz H. G. Pereira. We are grateful to CODEVASF-MG and IBAMA-MG for field collection and financial support (YS) and also to Daniel C. Carvalho (PUC-MG) for loan samples. This research was also supported by the Brazilian agencies FAPESP (BFM., FF., and $\mathrm{CO}$ ), $\mathrm{CNPq}$ (FF, CO), and CAPES (B.F.M.). This work was developed as Master's dissertation in Biological Sciences with emphasis in Genetics by the first author.

\section{Literature Cited}

Abreu, M. M., L. H. G. Pereira, V. B. Vila, F. Foresti \& C. Oliveira. 2009. Genetic variability of two populations of Pseudoplatystoma reticulatum from the Upper Paraguay River Basin. Genetics and Molecular Biology, 32: 868-873.

Agostinho, A. A., S. M. Thomaz, C. V. Minte-Vera \& K. O .Winemiller. 2000. Biodiversity in the high Paraná River floodplain. Pp. 89-118. In: Gopal, B., W. J. Junk \& J. A. Davis (Eds.). Biodiversity in wetlands: assessment, function and conservation. Leiden, Backhuys Publishers.

Alam, M. S. \& M. S. Islam. 2005. Population genetic structure of Catla catla (Hamilton) revealed by microsatellite DNA markers. Aquaculture, 246: 151-160.

Aljanabi, S. M. \& I. Martinez. 1997. Universal and rapid saltextraction of high quality genomic DNA for PCR-based techniques. Nucleic Acids Research, 25: 4692-4693.

Barbosa, A. C. D. R., F. Galzerani, T. C. Corrêa, P. M. Galetti \& T. Hatanaka. 2008. Description of novel microsatellite loci in the Neotropical fish Prochilodus argenteus and cross-amplification in P. costatus and P. lineatus. Genetics and Molecular Biology, 31: 357-360.

Barroca, T. M., F. P. Arantes, B. F. Magalhães, F. F. Siqueira, C. C. R. Horta, I. F. Pena, J. A. Dergam \& E. Kalapothakis. 2012.
Genetic diversity and population structure of Prochilodus costatus and Prochilodus argenteus preceding dam construction in the Paraopeba River, São Francisco River Basin, Minas Gerais, Brazil. Open Journal of Genetics, 2: 121-130.

Brookfield, J. F.Y. 1996. A simple new method for estimating null allele frequency from heterozygote deficiency. Molecular Ecology, 5: 453-455.

Calcagnotto, D. \& R. DeSalle. 2009. Population genetic structuring in pacu (Piaractus mesopotamicus) across the Paraná-Paraguay basin: evidence from microsatellites. Neotropical Ichthyology, 7: 607-616.

Camargo, S. A. F. \& M. Petrere. 2001. Social and financial aspects of the artisanal fisheries of Middle São Francisco River, Minas Gerais, Brazil. Fisheries Management and Ecology, 8: 163-171.

Carreras-Carbonell, J., E. Macpherson \& M. Pascual. 2006. Population structure within and between subspecies of the Mediterranean triplefin fish Tripterygion delaisi revealed by highly polymorphic microsatellite loci. Molecular Ecology, 15: 3527-3539.

Carvalho-Costa, L. F., T. Hatanaka \& P. M. Galetti. 2008. Evidence of lack of population substructuring in the Brazilian freshwater fish Prochilodus costatus. Genetics and Molecular Biology, 31: 377-380.

Castro, R. M. C. \& R. P. Vari. 2004. Detritivores of the South American Fish Family Prochilodontidae (Teleostei: Ostariophysi: Characiformes): A Phylogenetic and revisionary study. Washington, Smithsonian Books.

Cavalli-Sforza, L. L. \& A. W. F. Edwards. 1967. Phylogenetic analysis: models and estimation procedures. American Journal of Human Genetics, 19: 233-257.

Chevolot, M., J. R. Ellis, G. Hoarau, A. D. Rijnsdorp, W. T. Stam \& J. L. Olsen. 2006. Population structure of the thornback ray (Raja clavata L.) in British waters. Journal of Sea Research, 56: 305-316.

Chistiakov, D. A., B. Hellemans \& F. A. M. Volckaert. 2006. Microsatellites and their genomic distribution, evolution, function and applications: A review with special reference to fish genetics. Aquaculture, 255: 1-29.

DeWoody, J. A. \& J. C. Avise. 2000. Microsatellite variation in marine, freshwater and anadromous fishes compared with other animals. Journal of Fish Biology, 56: 461-473.

Excoffier, L., G. Laval \& S. Schneider. 2005. Arlequin (version 3.0): An integrated software package for population genetics data analysis. Evolutionary Bioinformatics Online, 1: 4750 .

Excoffier, L., P. Smouse \& J. Quattro. 1992. Analysis of molecular variance inferred from metric distances among DNA haplotypes: Application to human mitochondrial DNA restriction data. Genetics, 131: 479-491.

Godinho, A. L., M. F. G. Brito \& H. P. Godinho. 2003. Pesca nas corredeiras de Buritizeiro: da ilegalidade à gestão participativa. Pp. 347-360. In: Godinho, H. P. \& A. L. Godinho (Eds.). Águas, peixes e pescadores do São Francisco das Minas Gerais. Belo Horizonte, PUC-Minas.

Godinho, A. L. \& H. P. Godinho. 2003. Breve visão do São Francisco. Pp. 15-24. In: Godinho, H. P. \& Godinho, A. L. (Eds.). Águas, peixes e pescadores do São Francisco das Minas Gerais. Belo Horizonte, PUC-Minas.

Godinho, A. L. \& B. Kynard. 2006. Migration and spawning of radio-tagged zulega Prochilodus argenteus in a dammed Brazilian 
river. Transactions of the American Fisheries Society, 135: 811824.

Godoy, M. P. 1975. Peixes do Brasil - Sub ordem Characoidei, Bacia do Rio Mogi Guassu. Piracicaba, Ed. Franciscana.

Goulding, M. 1981. Man and fisheries on an Amazon frontier. The Hague, Dr. W. Junk Publishers.

Guo, S. W. \& E. A. Thomson. 1992. Performing the Exact Test of Hardy-Weinberg proportion for multiple alleles. Biometrics, 48: 361-372.

Hatanaka, T. \& P. M. Galetti. 2003. RAPD markers indicate the occurrence of structured populations in a migratory freshwater fish species. Genetics and Molecular Biology, 26: $19-25$.

Hatanaka, T., F. Henrique-Silva \& P. M. Galetti. 2006. Population substructuring in a migratory freshwater fish Prochilodus argenteus (Characiformes, Prochilodontidae) from the São Francisco River. Genetica, 126: 153-159.

Hrbek, T., M. Crossa \& I. P. Farias. 2007. Conservation strategies for Arapaima gigas (Schinz, 1822) and the Amazonian várzea ecosystem. Brazilian Journal of Biology, 67: 909-917.

Iervolino, F., E. K. Resende \& A. L. S. Hilsdorf. 2010. The lack of genetic differentiation of pacu (Piaractus mesopotamicus) populations in the Upper-Paraguay Basin revealed by the mitochondrial DNA D-loop region: Implications for fishery management. Fisheries Research, 101:27-31.

Kimura, M. \& J. F. Crow. 1964. The number of alleles that can maintained in a finite populations. Genetics, 49: 725-738.

Kimura, M. \& T. Ohta. 1978. Stepwise mutation model and distribution of allelic frequencies in a finite populations. Proceedings of the National Academy of Sciences USA, 75: 2868-2872.

Lopes, C. M., F. S. Almeida, M. L. Orsi, S. G. C. Britto, R. N. Sirol \& L. M. K. Sodré. 2007. Fish passage ladders from Canoas Complex - Paranapanema River: evaluation of genetic structure maintenance of Salminus brasiliensis (Teleostei: Characiformes). Neotropical Ichthyology, 5: 131-138.

Lowe-McConell, R. 1975. Fish communities in tropical freshwaters. New York, Longman Publishing.

Matsumoto, C. K. \& A. W. S. Hilsdorf. 2009. Microsatellite variation and population genetic structure of a neotropical endangered Bryconinae species Brycon insignis Steindachner, 1877: implications for its conservation and sustainable management. Neotropical Ichthyology, 7: 395-402.

Menezes, N. A. 1996. Methods for assessing freshwaters fish diversity. Pp. 289-295. In: Bicudo, C. E. M. \& N. A. Menezes (Eds.). Biodiversity in Brazil: a first approach. São Paulo, CNPq.

Moojen, J. 1940. Aspectos ecológicos do alto São Francisco: o pescador. O Campo, 11: 22-24.

van Oosterhout, C., W. F. Hutchinson, D. P. M. Wills \& P. Shipley. 2004. MICRO-CHECKER: software for identifying and correcting genotyping errors in microsatellite data. Molecular Ecology Notes, 4: 535-538.

Peakall, R. \& P. E. Smouse. 2006. GENALEX 6: genetic analysis in Excel. Population genetic software for teaching and research. Molecular Ecology Notes, 6: 288-295.

Pereira, L. H. G., F. Foresti \& C. Oliveira. 2009. Genetic structure of the migratory catfish Pseudoplatystoma corruscans (Siluriformes: Pimelodidae) suggest homing behavior. Ecology of Freshwater Fish, 18: 215-225.
Pinheiro, C. V. L. 1981. Relatório de pesca no lago de Sobradinho para o ano de 1980. Juazeiro, SUDEPE.

Piry, S., A. Alapetite, J. M. Cornuet, D. Paetkau, L. Baudouin \& A. Estoup. 2004. Geneclass2: a software for genetic assignment and first-generation migrant detection. Journal of Heredity, 95: 536-539.

Pompeu, P. S. \& C. B. M. Alves. 2003. Local fish extinction in a small tropical lake in Brazil. Neotropical Ichthyology, 1: 133135.

Pompeu, P. S. \& H. P. Godinho. 2003. Ictiofauna de três lagoas marginais do médio São Francisco. Pp. 167-181. In: Godinho, H. P. \& A. L. Godinho(Eds.). Águas, peixes e pescadores do São Francisco das Minas Gerais. Belo Horizonte, PUCMinas.

Pompeu, P. S. \& H. P. Godinho. 2006. Effects of extended absence of flooding on the fish assemblages of three floodplain lagoons in the middle São Francisco River, Brazil. Neotropical Ichthyology, 4: 427-433.

Pritchard, J. K., M. Stephens \& P. Donnelly. 2000. Inference of population structure using multilocus genotype data. Genetics, 155: 945-959.

Raymond, M. \& F. Rousset. 1995. Genepop (version 1.2): population genetics software for exact tests and ecumenicism. Journal of Heredity, 86: 248-249.

Revaldaves, E., E. Renesto \& M. F. P. S. Machado. 1997. Genetic variability of Prochilodus lineatus (Characiformes, Prochilodontidae) in the upper Paraná river. Brazilian Journal of Genetics, 20: 381-388.

Rice, W. R. 1989. Analyzing tables of statistical tests. Evolution, 43: 223-225.

Saitou, N. \& M. Nei. 1987. The neighbor-joining method: a new method for reconstructing phylogenetic trees. Molecular Biology and Evolution, 4: 406-425.

Sanches, A., P. M. Galetti, F. Galzerani, J. Derazo, B. CutilakBianchi \& T. Hatanaka. 2012. Genetic population structure of two migratory freshwater fish species (Brycon orthotaenia and Prochilodus argenteus) from the São Francisco River in Brazil and its significance for conservation. Latin American Journal of Aquatic Research, 40: 177-186.

Santos, M. C. F., M. L. Ruffino \& I. P. Farias. 2007. High levels of genetic variability and panmixia of the tambaqui Colossoma macropomum (Cuvier, 1816) in the main channel of the Amazon River. Journal of Fish Biology, 71: 33-44.

Sato, Y., N. Bazzoli, E. Rizzo, M. B. Boschi \& M. O. T. Miranda. 2005. Influence of the Abaeté River on the reproductive success of the neotropical migratory teleost Prochilodus argenteus in the São Francisco River, downstream from the Três Marias Dam, southeastern Brazil. River Research and Applications, 21: 939-950.

Sato, Y., E. L. Cardoso \& J. C. C. Amorim. 1987. Peixes das lagoas marginais do rio São Francisco a montante da represa de Três Marias, Minas Gerais. Brasília, CODEVASF.

Sato, Y., E. L. Cardoso, A. L. Godinho \& H. P. Godinho. 1996. Hypophysation parameters of the fish Prochilodus marggravvi obtained in routine hatchery station conditions. Revista Brasileira de Biologia, 56: 59-64.

Sato, Y. \& H. P. Godinho. 2003. Migratory fishes of the São Francisco river. Pp. 195-232. In: Carolsfeld, J., B. Harvey, C. Ross \& A. Baer (Eds.). Migratory fishes of South America: biology, fisheries and ecological status. Victoria, World Fisheries Trust. 
Sivasundar, A., E. Bermingham \& G. Ortí. 2001. Population structure and biogeography of migratory freshwater fishes (Prochilodus: Characiformes) in major South American rivers. Molecular Ecology, 10: 407-417.

Slatkin, M. 1985. Rare alleles as indicators of gene flow. Evolution, 39: 53-65.

Slatkin, M. 1995. A measure of population subdivision based on microsatellite allele frequencies. Genetics, 139: 457-462.

Swofford, D. L. 2003. Paup*: Phylogenetic analysis using parsimony (*and other methods), version 4. Sunderland, Sinauer Associates.

Toledo, S. A., M. P. Godoy \& E. P. Santos. 1986. Curva de migração do curimbatá, Prochilodus scrofa (Pisces, Prochilodontidae) na bacia superior do rio Paraná, Brasil. Revista Brasileira de Biologia, 46: 447-452.

Vari, R. P. 1983. Phylogenetic relationships of the families Curimatidae, Prochilodontidae, Anostomidae and Chilodontidae (Pisces, Characiformes). Washington, Smithsonian Books.

Wright, S. 1931. Evolution in Mendelian populations. Genetics, 16: 97.

Wright, S. 1951. The genetical structure of populations. Annals of Eugenics, 15: 323-354.

Yeh, F. C \& T. J. B. Boyle. 1997. Population genetics analysis of co-dominant and dominant markers and quantitative traits. Belgian Journal of Botany, 129: 157.

Zhang, D. X. \& G. M. Hewitt. 2003. Nuclear DNA analyses in genetic studies of populations: practice, problems and prospects. Molecular Ecology, 12: 563-584.

Submitted December 14, 2012

Accepted June 5, 2013 by Alexandre Hilsdorf

Published September 30, 2013 